\title{
Penerapan Corporate Governance terhadap Kinerja Perusahaan
}

\author{
Indah Permata Sari \\ Universitas Sumatera Utara, Medan \\ indah2151@gmail.com
}

Corporate governance adalah sistem yang mengarahkan dan mengendalikan perusahaan dengan tujuan, agar mencapai keseimbangan antara kewenangan perusahaan dan pertanggungjawaban kepada stakeholders. Kinerja Perusahaan merupakan hasil dari kegiatan manajemen di setiap perusahaan. Pada dasarnya penerapan corporate governance tidak semudah memahami konsepnya. Penerapan dan pengelolaan good corporate governance (GCG) merupakan sebuah konsep yang menekankan pentingnya hak pemegang saham untuk memperoleh informasi dengan benar, akurat, dan tepat waktu. Oleh karena itu, baik perusahaan publik maupun tertutup harus memandang GCG bukan sebagai aksesoris belaka, tetapi sebagai upaya peningkatan kinerja dan nilai perusahaan. Masih banyak penyimpangan yang muncul akibat tidak adanya integritas dari manajemen perusahaan. Timbulnya ketidaktaatan, kesalahpahaman, konflik peran serta fungsi pengambilan keputusan. Penerapan Good Corporate Governance (GCG) salah satunya dapat didorong dari sisi regulasi. Dorongan tersebut adalah dengan dituangkannya prinsip-prinsip dasar GCG ke dalam regulasi. GCG menitikberatkan perlindungan terhadap pemegang saham terutama pemegang saham minoritas, kepentingan tersebut pada dasarnya telah diakomodasi oleh Undang-Undang Nomor 40 Tahun 2007 tentang Perseroan Terbatas namun untuk tidak dapat dikatakan sempurna, dimana kehadiran Komite Audit, Komite Nominasi atau Remunerasi telah menjadi bukti ketertinggalan dengan perkembangan bisnis saat ini.Studi ini bertujuan untuk menjelaskan penerapan dan implementasi tata kelola corporate governance yang baik terhadap kinerja perusahaan. Manfaat penerapan corporate goveranance adalah untuk meningkatkan kinerja perusahaan, mempermudah diperolehnya dana pembiayaan dan mengembalikan kepercayaan kepada investor. Penelitian ini dilakukan melalui studi literatur dengan mengumpulkan jurnal-jurnal dan buku-buku literature terkait dengan penerapan tata kelola corporate governance terhadap kinerja perusahaan.

Kata kunci : corporate governance, stakeholders, kinerja perusahaan. 


\section{PENDAHULUAN}

Corporate Governance merupakan sistem pengendalian dan pengaturan perusahaan yang dapat dilihat dari mekanisme hubungan antara berbagai pihak yang mengurus perusahaan (hard definition), maupun ditinjau dari "nilai-nilai" yang terkandung dari mekanisme pengelolaan itu sendiri (soft definition). Corporate governance juga memberikan suatu struktur yang memfasilitasi penentuan sasaran-sasaran dari suatu perusahaan, dan sebagai sarana untuk menentukan teknik monitoring kinerja.

Penerapan corporate governance dibutuhkan untuk menjaga konsistensi dan kepercayaan masyarakat terhadap sebuah perusahaan. Penerapan corporate governance juga memerlukan langkah panjang dalam mengimplementasikan prinsip-prinsipnya, dimana akan menanamkan nilai-nilai yang membentuk sebuah proses budaya dalam menata kelola perusahaan. Perusahaan akan berupaya semaksimal mungkin untuk mencapai tujuan yang telah direncanakan. Melalui laba yang diperoleh, perusahaan akan mampu memberikan deviden kepada para pemegang saham, meningkatkan pertumbuhan perusahaan dan mempertahankan kelangsungan hidup perusahaan. Lima prinsip corporate governance (Wulandari, 2019) yaitu transparansi, akuntabilitas, responsibilitas, independensi dan kesetaraan.

Implementasi corporate governance di Indonesia sampai saat ini masih belum memenuhi harapan, oleh karena itu penerapan corporate governance memerlukan komitmen yang kuat untuk mewujudkannya. Implementasi di Indonesia masih menghadapi Kendala yang luar biasa sampai saat ini corporate governance belum memberikan tata kelola yang baik bagi perusahaan. Kinerja perusahaan merupakan hasil dari kegiatan manajemen di setiap perusahaan. Parameter yang sering digunakan untuk menilai kinerja suatu perusahaan adalah dengan menggunakan pendekatan dimana informasi keuangan diambil dari laporan keuangan.

Kinerja keuangan dapat diukur dengan beberapa pendekatan rasio keuangan, baik likuiditas, profitabilitas, solvabilitas, aktivitas maupun rasio pasar. Kebijakan dan keputusan para investor dalam menginvestasikan modalnya ke dalam perusahaan lebih dipengaruhi oleh rasio profitabilitas yang dimiliki oleh suatu perusahaan dibandingkan dengan rasio lainnya, karena investor menganggap bahwa rasio profitabilitas dapat memberikan gambaran tentang tingkat pengembalian atau keuntungan yang akan diterima oleh investor dari investasinya.menyatakan bahwa kinerja perusahaan dipengaruhi oleh beberapa faktor, antara lain terkonsentrasi atau tidak terkonsentrasinya kepemilikan, manipulasi laba, serta pengungkapan laporan keuangan. Suatu perusahaan dengan manajemen yang menerapkan sistem pengelolaan yang baik akan memberikan perlindungan dan jaminan hak kepada para stakeholdersnya. Oleh karena itu, manajemen berkewajiban memberikan informasi akurat tentang kondisi perusahaan yang sebenarnya.

Forum for Corporate Governance in Indonesia(FCGI) mendefinisikan Corporate Governance sebagaiseperangkat peraturan yang mengatur hubungan antara pemegang saham, pengurus (pengelola) perusahaan, pihak kreditur, pemerintah, karyawan serta para pemegang kepentingan intern dan esktern lainnya yang berkaitan dengan hak-hak dan kewajiban mereka atau dengan kata lain suatu sistem yang mengatur dan mengendalikanperusahaan. Salah satu topik utama dalam tata kelola perusahaan adalah menyangkut masalah akuntabilitas dan tanggung jawab mandat, khususnya implementasi pedoman dan mekanisme untuk memastikan perilaku yang baik dan melindungi kepentingan pemegang saham. Tujuan dari good corporate 
governance adalah untuk menciptakan nilai tambah bagi semua pihak yang berkepentingan (stakeholders). Secara teoritis, pelaksanaan good corporate governance dapat meningkatkan nilai perusahaan, dengan meningkatkan kinerja keuangan mereka, mengurangi risiko yang mungkin dilakukan oleh dewan komisaris dengan keputusankeputusan yang menguntungkan diri sendiri dan umumnya good corporate governance dapat meningkatkan kepercayaan investor.

\section{MANFAAT PENERAPAN CORPORATE GOVERNANCE}

Penerapan good corporate governance tidak hanya melindungi kepentingan para investor saja tetapi juga akan dapat mendatangkan banyak manfaat dan keuntungan bagi perusahaan terkait dan juga pihak-pihak lain yang mempunyai hubungan langsung maupun tidak langsung dengan perusahaan(Dwiridotjahjono, 2011). Berbagai manfaat dan keuntungan yang diperoleh dengan penerapan good corporate governance dapat disebut antara lain:

1. Dengan penerapan good corporate governance perusahaan dapat meminimalkan agency cost, yaitu biaya yang timbul sebagai akibat dari pendelegasian kewenangan kepada manajemen, termasuk biaya penggunaan sumber daya perusahaan oleh manajemen untuk kepentingan pribadi maupun dalam rangka pengawasan terhadap perilaku manajemen itu sendiri.

2. Perusahaan dapat meminimalkan cost of capital, yaitu biaya modal yang harus ditanggung bila perusahaan mengajukan pinjaman kepada kreditur. Hal ini sebagai dampak dari pengelolaan perusahaan secara baik dan sehat yang pada gilirannya menciptakan suatu referensi positif bagi para kreditur.

3. Dengan good corporate governance proses pengambilan keputusan akan berlangsung secara lebih baik sehingga akan menghasilkan keputusan yang optimal, dapat meningkatkan efisiensi serta terciptanya budaya kerja yang lebih sehat. Ketiga hal ini jelas akan sangat berpengaruh positif terhadap kinerja perusahaan, sehingga kinerja perusahaan akan mengalami peningkatan. Berbagai penelitian telah membuktikan secara empiris bahwa penerapan good corporate governance akan mempengaruhi kinerja perusahaan secara positif.

4. Good corporate governance akan memungkinkan dihindarinya atau sekurangkurangnya dapat diminimalkannya tindakan penyalahgunaan wewenang oleh pihak direksi dalam pengelolaan perusahaan. Hal ini tentu akan menekan kemungkinan kerugian bagi perusahaan maupun pihak berkepentingan lainnya sebagai akibat tindakan tersebut.

5. Nilai perusahaan di mata investor akan meningkat sebagai akibat dari meningkatnya kepercayaan mereka kepada pengelolaan perusahaan tempat mereka berinvestasi. Peningkatan kepercayaan investor kepada perusahaan akan dapat memudahkan perusahaan mengakses tambahan dana yang diperlukan untuk berbagai keperluan perusahaan, terutama untuk tujuan ekspansi.

Pelaksanaan good corporate governance dilakukan dengan menggunakan prinsip-prinsip, yaitu:

1. Hak-hak para pemegang saham, yang harus diberi informasi dengan benar dan tepat pada waktunya mengenai perusahaan, dapat ikut berperan serta dalam pengambilan keputusan atas perusahaan, dan turut memperoleh bagian dari keuntungan perusahaan.

2. Perlakuan sama terhadap pemegang saham, terutama kepada pemegang sahamminoritas dan pemegang saham asing, dengan keterbukaan informasi yang 
penting serta melarang pembagian untuk pihak sendiri dan perdagangan saham oleh orang dalam (insider trading).

3. Peranan pemegang saham harus diakui sebagaimana ditetapkan oleh hukum dan kerjasama yang aktif antara perusahaan serta para pemegang kepentingan dalam menciptakan kesejahteraan, lapangan kerja dan perusahaan yang sehat dari aspek keuangan.

4. Pengungkapan yang akurat dan tepat pada waktunya serta transparasi mengenai semua hal yang penting bagi kinerja perusahaan, kepemilikan, serta para pemegang kepentingan (stakeholders).

5. Tanggungjawab pengurus dalam manajemen, pengawasan manajemen serta pertanggungjawaban kepada perusahaan dan para pemegang saham.

Dalam tata kelola perusahaan yang baik seluruh kegiatan pengelolaan perusahaan akan selalu dilandasi prinsip-prinsip sebagai berikut:

a. Transparency (keterbukaan) : yaitu keterbukaan dalam melaksanakan proses pengambilan keputusan dan keterbukaan dalam mengemukakan informasi materiil dan relevan mengenai perusahaan. Perusahaan akan menyediakan informasi yang cukup, akurat, dan tepat waktu kepada seluruh stakeholders, sehingga pihak-pihak yang mempunyai keterkaitan dengan perusahaan, seperti pemegang saham, Bapepam, Bursa Efek, pegawai, pelanggan, pemasok dan stakeholders lainnya.

b. Accountability (akuntabilitas) : yaitu kejelasan fungsi, pelaksanaan dan pertanggungjawaban organ-organ perusahaan sehingga pengelolaan perusahaan terlaksana secara efektif. Akuntabilitas menciptakan pengawasan efektif yang mendasarkan pada keseimbangan hak dan tanggungjawab antara pemegang saham, dewan komisaris dan direksi.

c. Responsibility (tanggungjawab) : yaitu kesesuaian didalam pengelolaan perusahaan terhadap peraturan perundang-undangan yang berlaku dan prinsip-prinsip perusahaan yang sehat. Perusahaan memenuhi dan mematuhi hukum dan peraturan perundangundangan yang berlaku, termasuk didalamnya pemenuhan hak-hak stakeholders, keselamatan dan kesehatan kerja, dan penghindaran dari praktik bisnis yang tidak sehat.

d. Independency (Kemandirian) : yaitu suatu keadaan dimana perusahaan dikelola secara profesional tanpa benturan kepentingan dan intervensi 12 dari pihak manapun yang tidak sesuai dengan peraturan perundangundangan yang berlaku dan prinsip-prinsip perusahaan yang sehat. Direksi dalam menjalankan tugas-tugas kepengurusan perusahaan dan dewan komisaris dalam melaksanakan peran pengawasan atas jalannya perusahaan bebas dari intervensi pihak luar.

e. Fairness (Kewajaran) : yaitu keadilan dan kesetaraan didalam memenuhi hak-hak stakeholders yang timbul berdasarkan perjanjian dan peraturan perundang-undangan yang berlaku. Terhadap stakeholders tersebut diberikan perlindungan, kesempatan dan perlakuan yang wajar untuk menuntut jika terjadi pelanggaran terhadap hak mereka.

\section{PENYEBAB GOOD CORPORATE GOVERNANCE BELUM BERJALAN OPTIMAL DI INDONESIA}

Perusahaan-perusahaan di Indonesia belum mampu melaksanakan corporate governance dengan sungguh-sungguh sehingga perusahaan mampu mewujudkan prinsipprinsip good corporate governance dengan baik. Hal ini disebabkan oleh adanya sejumlah kendala yang dihadapi oleh perusahaan-perusahaan tersebut pada saat perusahaan berupaya 
melaksanakan corporate governance demi terwujudnya prinsip-prinsip good corporate governance dengan baik. Kendala ini dapat dibagi tiga, yaitu kendala internal, kendala eksternal, dan kendala yang berasal dari struktur kepemilikan. Kendala internal meliputi kurangnya komitmen dari pimpinan dan karyawan perusahaan, rendahnya tingkat pemahaman dari pimpinan dan karyawan perusahaan tentang prinsip-prinsip good corporate governance, kurangnya panutan atau teladan yang diberikan oleh pimpinan, belum adanya budaya perusahaan yang mendukung terwujudnya prinsip-prinsip good corporate governance, serta belum efektifnya sistem pengendalian internal. Kendala eksternal dalam pelaksanaan corporate governance terkait dengan perangkat hukum, aturan dan penegakan hukum (lawenforcement)(Wibowo, 2010).

Baik kendala internal maupun kendala eksternal sama-sama penting bagi perusahaan, namun demikian, jika kendala internal bisa dipecahkan maka kendala eksternal akan lebih mudah diatasi. Kendala yang ketiga adalah kendala yang berasal dari struktur kepemilikan. Berdasarkan persentasi kepemilikan dalam saham, kepemilikan terhadap perusahaan dapat dibedakan menjadi dua, yaitu kepemilikan yang terkonsentrasi dan kepemilikan yang menyebar.Kepemilikan yang terkonsentrasi terjadi pada saat suatu perusahaan dimiliki secara dominan oleh seseorang atau sekelompok orang saja (40,00\% atau lebih). Kepemilikan yang menyebar terjadi pada saat suatu perusahaan dimiliki oleh pemegang saham yang banyak dengan jumlah saham yang kecil-kecil (satu pemegang saham hanya memiliki saham sebesar $5 \%$ atau kurang). Salah satu dampak negatif yang ditimbulkan oleh struktur kepemilikan adalah perusahaan tidak dapat mewujudkan prinsip keadilan dengan baik karena pemegang saham yang terkonsentrasi pada seseorang atau sekelompok orang dapat menggunakan sumberdaya perusahaan secara dominan sehingga dapat mengurangi nilai perusahaan. Sama seperti halnya kendala eksternal, dampak negatif yang ditimbulkan dari struktur kepemilikan dapat diatasi jika perusahaan memiliki sistem pengendalian internal yang efektif, seperti mempunyai sistem yang menjamin pendistribusian hak-hak dan tanggung jawab secara adil di antara berbagai partisipan dalam organisasi (Dewan Komisaris, Dewan Direksi, manajer, pemegang saham, serta pemangku kepentingan lainnya), dan dampak negatif ini juga akan hilang jika dalam stuktur organisasinya, perusahaan mempunyai Komisaris Independen dengan jumlah tertentu dan memenuhi kualifikasi yang ditentukan (syarat-syarat yang ditentukan untuk menjadi Komisaris Independen)

\section{SISTEM PENILAIAN PELAKSANAAN CORPORATE GOVERNANCE}

Penilaian terhadap pelaksanaan good corporate governance di Indonesia dilakukan oleh lembaga independen yaitu: Forum for Corporate Governance in Indonesia (FCGI). Penilaian dilakukan dengan menggunakan kuesioner yang dijawab oleh pihak manajemen perusahaan. Aspek yang dinilai meliputi Hak-hak Pemegang Saham, Kebijakan Corporate Governance, Praktek-praktek Corporate Governance, Pengungkapan, dan Fungsi Audit. Penentuan skor pelaksanaan dilakukan melalui metode rata-rata tertimbang, dengan bobot masing-masing aspek sebagai berikut:

1. Hak-hak Pemegang Saham (20\%).

2. Kebijakan Corporate Governance (15\%).

3. Praktek-praktek Corporate Governance (30\%).

4. Pengungkapan (Disclosure) $(20 \%)$ dan

5. Fungsi Audit (15\%) 
Mekanisme corporate governance merupakan suatu aturan main, prosedur dan hubungan yang jelas antara pihak yang mengambil keputusan dengan pihak yang melakukan kontrol/pengawasan terhadap keputusan tersebut. Mekanisme governance diarahkan untuk menjamin dan mengawasi berjalannya sistem governance dalam sebuah organisasi. Mekanisme pengendalian internal adalah pengendalian perusahaan yang dilakukan dengan membuat seperangkat aturan yang mengatur tentang mekanisme bagi hasil, baik yang berupa keuntungan, return maupun risiko-risiko yang disetujui oleh prinsipal dan agen. Salah satu pilihan mekanisme pengendalian internal untuk menyamakan kepentingan pemegang saham dan manajer adalah kontrak insentif jangka panjang.Dengan demikian, manajer akan termotivasi untuk meningkatkan nilai perusahaan atau meningkatkan kemakmuran pemegang saham karena hal tersebut juga akan meningkatkan kekayaan manajer sendiri.Mekanisme pengendalian eksternal adalah pengendalian perusahaan yang dilakukan oleh pasar. Menurut teori pasar untuk pengendalian perusahaan (market for corporate control), pada saat diketahui bahwa manajemen berperilaku menguntungkan diri sendiri, kinerja perusahaan akan menurun yang direfleksikan oleh nilai saham perusahaan. Pada kondisi tersebut, kelompok menajer lain akan menggantikan manajer yang sedang memegang jabatan. Dengan demikian bekerjanya market for corporate control bisa menghambat tindakan menguntungkan diri manajer sendiri.

\section{METODE PENELITIAN}

Penelitian ini menggunakan metode deskriptif dengan melakukan analisa atas penelitian-penelitian terdahulu baik yang bersumber dari jurnal, buku, dan jenis artikel terpercaya lainnya.

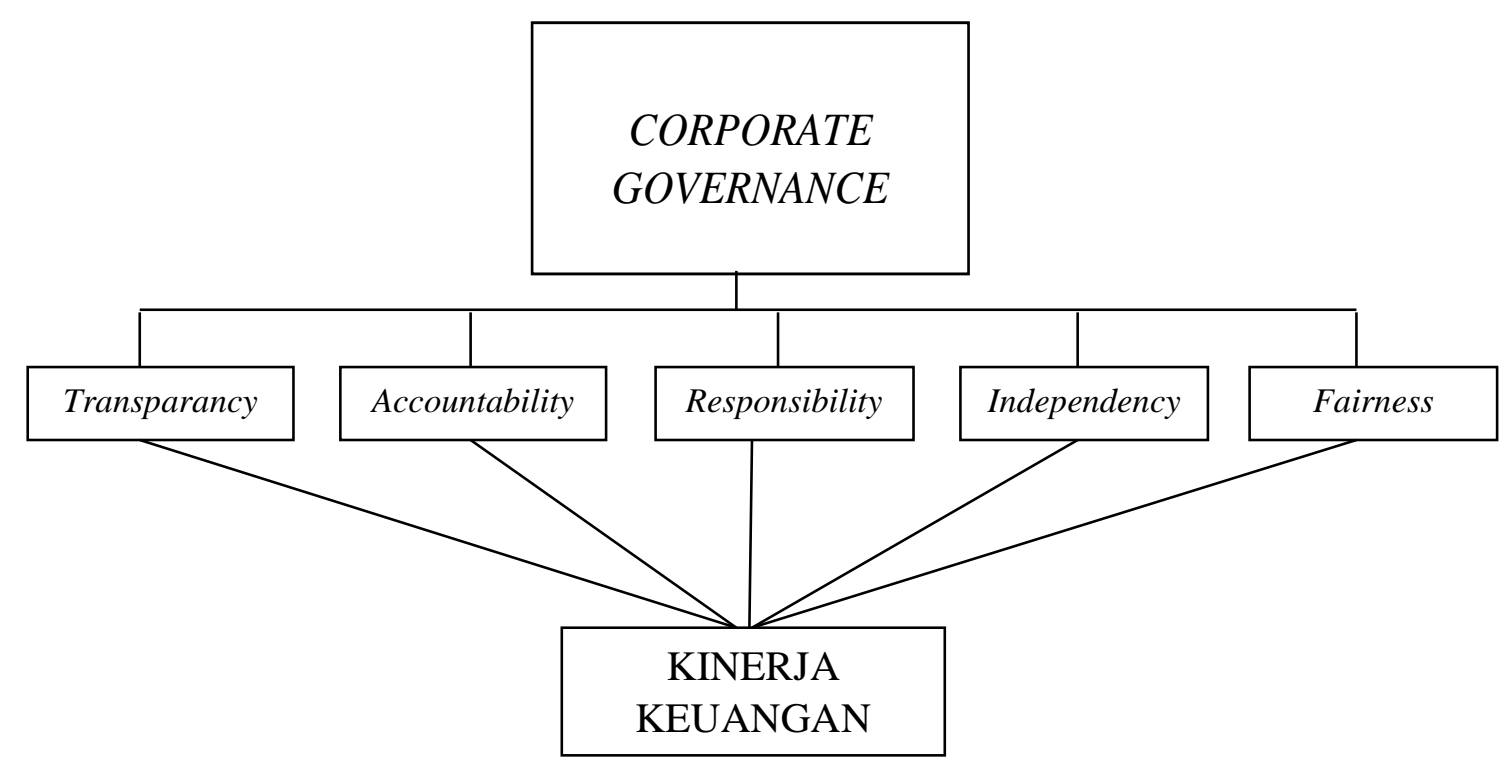

VI. HASIL DAN PEMBAHASAN

\section{GOOD CORPORATE GOVERNANCE}

Good corporate governance adalah suatu sistem pengendalian internal perusahaan yang memiliki tujuan utama mengelola risiko yang suignfikan guna memenuhi tujuan 
bisnisnya melalui pengamanan asset perusahaan dan meningkatkan nilai nvestasi pemegang saham dalam jangka panjang. Adapaun tujuan penerapan good corporate governance suatu perusahaan adalah sebagai berikut :

1. Mengembangkan dan meningkatkan nilai perusahaan.

2. Mengelola sumber daya dan resiko secara lebih efektif dan efisien.

3. Meningkatkan disiplin dan tanggng-jawab dari organ peruusahaan demi menjaga kepentingan para Shareholder dan Stakeholder perusahaan.

4. Meningkatkan kontribusi perusahaan (khususnya perusahaanperusahaan pemerintah) terhadap perekonomian nasional.

5. Meningkatkaninvestasi nasional.

6. Mensukseskan program privatisasi perusahaanperusahaan pemerintah. Indikator dalam penerapan dalam good corporate governance ada beberapa yaitu ukuran dewan komisaris, dewan komisaris independen, kepemilikan manajerial, kepemilikan institusional, dan komite audit. Adapun pengukuran untuk perhitungan dalam penelitian ini yakni menggunakan kepemilikan manajerial yang di mana rumusnya sebagai berikut :

$$
\mathrm{KM}=\frac{\text { Jumlah Saham Manajemen }}{\text { Total Saham Beredar }} x 100 \%
$$

\section{NILAI PERUSAHAAN}

Nilai perusahaan merupakan persepsi investor kepada tingkat keberhasilan suatu perusahaan yang sering dikait-kaitkan dengan harga saham. Dengan harga saham yang tinggi akan membuat nilai perusahaan juga ikut tinggi, dan meningkatkan kepercayaan pasar yang tidak hanya terhadap kinerja perusahaan saat ini namun juga pada prospek perusahaan dimasa mendatang. Tujuan utama sebuah perusahaan adalah dengan memaksimalkan nilai perusahaannya. Dan dengan meningkatkan nilai perusahaan juga sebuah prestasi akan sesuai dengan keinginan para pemiliknya, karena dengan peningkatan nilai perusaahaan, maka kesejahteraan para pemilik juga akan meningkat. Pengukuran dalam penelitian menggunakan rumus Price Earning Ratio (PER) yang rumusnya sebagai berikut :

$$
\mathrm{PER}=\frac{\text { Market } \text { price } \text { per } \text { share }}{\text { Earning per share }}
$$

\section{KINERJA KEUANGAN}

Adapun beberapa menurut para ahli yang menjelaskan pengertian kinerja keuangan diantaranya, (M. Thoyib, 2018) Kinerja keuangan adalah hasil atau prestasi yang telah dicapai oleh manajemen perusahaan dalam mengelola aset perusahaan secara efektif selama periode tertentu. Kinerja keuangan sangat dibutuhkan oleh perusahaan untuk mengetahui dan mengevaluasi tingkat keberhasilan perusahaan berdasarkan aktivitas keuangan yang telah dilaksanakan. Kinerja keuangan adalah prestasi kerja di bidang keuangan yang telah dicapai oleh perusahaan dan tertuang pada laporan keuangan dari perusahaan. Kinerja keuangan suatu perusahaan dapat dinilai dengan menggunakan alat analisis. Berdasarkan menurut para ahli tersebut adapun pengukuran kinerja keuangan dalam penelitian ini, sebagai berikut:

$$
\mathrm{ROE}=\frac{\text { Laba bersih setelah pajak }}{\text { Modal sendiri }}
$$




\section{KESIMPULAN}

Penelitian ini bertujuan untuk mengetahui penerapan corporate governance terhadap kinerja keuangan. Penerapan Good Corporate Governance (GCG) salah satunya dapat didorong dari sisi regulasi. Dorongan tersebut adalah dengan dituangkannya prinsip-prinsip dasar GCG ke dalam regulasi. GCG menitikberatkan perlindungan terhadap pemegang saham terutama pemegang saham minoritas, kepentingan tersebut pada dasarnya telah diakomodasi oleh Undang-Undang Nomor 40 Tahun 2007 tentang Perseroan Terbatas namun untuk tidak dapat dikatakan sempurna, dimana kehadiran Komite Audit, Komite Nominasi atau Remunerasi telah menjadi bukti ketertinggalan dengan perkembangan bisnis saat ini. Untuk prinsip transparency (transparansi) telah diatur dalam Pasal 66 ayat (1) dan (2) mengenai laporan tahunan dan Pasal 75 ayat (2) mengenai keterangan berkaitan perseroan dalam forum RUPS. Prinsip accountability (akuntabilitas) telah diatur dalam Pasal 92 ayat (1)untuk akuntabilitas dari Direksi dan Pasal 114 ayat (1) untuk akuntabilitas Dewan Komisaris. Prinsip responsibility (pertanggungjawaban) telah diatur dalam Pasal 74. Prinsip independency (kemandirian) telah diatur dalam Pasal 36 ayat (1). Dan prinsip terakhir yang merupakan jiwa dari GCG yaitu prinsip Fairness (kewajaran dan kesetaraan) merupakan perlindungan terhadap hak-hak pemegang saham Pasal 53 ayat (3) dan kesetaraan diantara para pemegang saham, hal ini untuk melindungi pemegang saham minoritas yang secara struktural lemah kedudukannya.

\section{DAFTAR PUSTAKA}

Dwiridotjahjono, J. (2011). Penerapan Good Corporate Governance : Manfaat Dan Tantangan Serta Kesempatan Bagi Perusahaan Publik Di Indonesia. Vol.5, No.2: hal. $101-112,101-112$.

M. Thoyib, R. W. (2018). ANALISIS KINERJA KEUANGAN DENGAN METODE ECONOMIC VALUE ADDED (VEA) DAN Q- TOBIN PADA PT. (PERSERO) PUPUK SRIWIDJAJA PALEMBANG. Jurnal Akuntanika, Vol. 4, No. 1 , JanuariJuni 2018, 122-134.

Wibowo, E. (2010). IMPLEMENTASI GOOD CORPORATE GOVERNANCE. Vol. 10, No. 2, Oktober $2010: 129-138,129-138$.

Wulandari, R. A. (2019). Tata Kelola Perusahaan Oleh Direksi PT BPR Dharma Nagari Dengan Menerapakan. Volume 2, Nomor 2, 2019, 2, 221-234. 